\title{
Assessing the High-Level Panel Report: rethinking the causes and consequences of threats to collective security
}

\author{
MAXWELL. O. CHIBUNDU'
}

\section{Introduction}

"First do no harm" is a creed now embraced well outside the medical profession. It is certainly an apt motto to adhere to when thinking about how to confront the complex and multifariously intertwined interests and institutions that constitute our contemporary international system. Harm is not simply the product of forces external to us, but can arise as readily from our own actions; specifically, as much from the misdiagnosis of a situation as from providing a wrong prescription, and the combination of both is likely to be lethal. The value in the proper diagnosis of a condition lies not only in the fact that it is more likely to yield the appropriate prescription, but just as crucially in that it affords an opportunity for the proper balancing of the cost of continued illness against the cost of the side effects that invariably inhere in the administering of any prescribed medication.

In reflecting on the Report of the High-Level Panel that forms the anchor for the collection of essays in this volume, one should pay attention to at least three sets of issues: (1) the diagnosis of the ailment; (2) the prescribed cures; and (3) the fit of diagnosis and prescription. The third is particularly important because of the possibility that even the most well-intentioned of prescriptions may themselves generate side effects that may constitute threats to the international order. ${ }^{2}$ My inquiry

1 The author thanks Prof. Peter Danchin and other contributors to this volume who participated at the Venice workshop for stimulating the ideas expressed in this chapter. He also acknowledges with gratitude the research and editing assistance of Ms. Lydia Nusshaum and Mr. Garth Olcese of the University of Maryland School of L.aw, I. D. class of 2009 and 2010.

2 This suggestion borrows from pharmacology. It is a familiar stance in that field that before establishing the efficacy of a medicine it must first be studied for its safety. 
into the Report of the High-Level Panel therefore proceeds along the following lines. First, I evaluate how well it has diagnosed the malady of the international legal order. My emphasis here is on the legal rather than the political; at least to the extent that one can sensibly comment on the former withoul being bogged down in the expediencies of the latter. Next, I take up the non-use of force prescriptions advanced by the HighLevel Panel. Here, I focus particularly on the panel's advocacy of increase in the collective use of sanctions as a legal tool to address or forestall threats to the international_order. I probe the extent to which this prescription is, on its own terms, efficacious, but more importantly, the extent to which it may itself generate threats to international order. Finally, I critique the broad sweep of the High-Level Panel's definition of "collective security," and its evident preference for a response that is both coercive and nonmilitaristic. I contend that both the analysis and prescriptions nonetheless miss the mark because they misstate the concept of collective security. In brief, while framing the concept as of one of harmonious coexistence within an ordered world, the prescriptions that are advanced focus essentially on preserving order through ostracism rather than inclusion. That is, the Report, while adopting in its diagnosis the postmodern stance of being all-inclusive, in its prescriptions exhibits the all-too-familiar and parochial western criminal law culture that emphasizes retribution and deterrence over the possible reconstitution of flawed societal normative orders. The reason for this disjuncture is, of course, the well-known reality that while anyone can talk a good talk, prescriptive rules reflect power imbalances. Given the number of times that "collective security" modeled on this reality has fallen short, the ultimate issue that this contribution addresses is whether it is at all feasible to depart from the familiar stance.

\section{Pre-Panel diagnosis of threats to collective security}

A threat is a potential (that is, not yet actualized) harm. ${ }^{3}$ In casting a situation as a threat, we posit the possibility of avoiding the putative

"Whether, as a legal matter, the threat to engage in an unlaw'ful act should, as a jurisprudential matter, be analyzed separately from actual engagement in the prohibited action is an interesting epistemological question that this chapter does not address. Compare, e.g., Nikolas Sturchler, The Threat of Force in International Law (New York: Cambridge University Press 2007) (contending that it is worthwhile to make such a distinction. and doing so in the context of the prohibitions of the "threat" and "use" of force). Sec UN Charter Article $2(4)$. 
harm through judicious action. The likelihood of a harm and the judiciousness of actions taken to avoid that harm suggest trade-offs, the fair values of which can only be gauged by reterence to extant realities. The edifice of the international order of the twentieth century amply embodied the view of the core threat to international order as arising from organized interstate conflicts. This view was the product of the experiences of the international system during the first half of the twentieth century. Interstate wars were seen as symptoms of the efforts of states to redress perceived imbalances in the distribution of power and resources. "Aggression," the dominant manifestation of that experience, could be checked only by enfolding states within a comprehensive system of mutual interdependence knit together under a political unbrella. Yeo. the prototypes of interstate conflicts - at least those that were to be most feared - were not (as they had been in the nineteenth century) of one-10one battles among states, but rather, as typified by the two "world wars," situations in which transnational alliances waged total war against each other. The regulation of these threats had to be multifaceled, but at core, it had to embody collectivized and comprehensive responses by the international community of states.

The creed and structures of the United Nations system reflect this diagnosis of the twentieth-century perils to international order. The core of the system was premised on the institutionalization of voluntary but universal admission to membership and participation in collective arrangements. The United Nations General Assembly was the epitome of the concept. Allied to but not necessarily subservient to the General Assembly were to be a host of functional organs and institutions, some with closer ties to the political institutions of the organization, others less so. The concept of the "sovereign equality" of members provided its legitimating inoculation against the practical realities of a world in which states in fact differed in size, military power, economic wealth, and political skills. This was buttressed by a philosophy in which cooperative behavior among states was to be encouraged through persuasion at virtually any cost, with coercion to be authorized only in the most exceptional of circumstances. This creed applied especially to the political organs of the United Nations, but it was also reflected in the organization and management of affiliated technical (or "specialized") institutions. Diplomacy (more particularly the use of negotiations, conciliations and ad hoc recommendations) was to be preferred, with the minimalist use of collective coercion in the form of sanctions, and ultimately military force, as weak last resorts. 
Two points thus stand out in the post-Second World War assessments of threats to collective security. Threats, though they originated from a variety of sources, were perceived as being primarily interstate and military in character. Similarly, responses to those threats were to be comprehensive, but for practical purposes, the focus was on avoiding interstate warfare.

Whether one accepts the accuracy of the diagnosis of the threats to collective security as seen by those who gathered in San Francisco in 1945, or the efficacy of their institutional prescriptions, it should be acknowledged that the world has in fact avoided the sorts of conflict that they had seen as primary threats to the international order, despite the existence of nuclear-armed camps. Moreover, the system as it was constituted recorded successes in other areas of cooperative behavior, notably the economic, and to a lesser extent, the social. In this sense, the San Francisco arrangement was a success.

The demand for reform today of course is predicated on the view that the nature of the threats to international order have changed materially. Total warfare by and among interstate alliances no longer seems likely. Undeniably, there are continuing military conflicts among states, but their destructive consequences appear no greater than those that arise from intrastate conflicts. Indeed, these latter wars may be more destructive because, aided and abetted by the concept of sovereignty, they have by and large escaped effective international regulation. ${ }^{4}$ And many of the perceived threats to the contemporary order - genocides, ethnic cleansings, terrorism, human rights violations, poverty, and dišease - have been spawned in the cauldron of internal conflicts. Along with these,

+ In some ways, the architecture of the United Nations system as conceive in Article 2 of the Charter creates a rather perverse incentive for dealing with internal wars. Article $2(7)$ clearly limits the authority of the United Nations w act in matters that are deemed internal. Article 2(4) superficially forbids member states similarly to intervene (at least through force) in those situations where such intervention might be seen as "interfering" in the "territorial integrity or political independence" of a member state. Since that decision is to be determined solely by the reigning government of a member state, Article 2(4) implicitly permits intervention that favors the ruling leadership. Assistance is most likely to be sought by a weak government whose internal hold on power is genuinely threatened by lack of mass support within the national political order. It is precisely in this situation of relative internal illegitimacy that support for the opposition from the outside is most likely to be viewed favorably - at least from a moral stance, although such support would run against the legal prohibition. The result, as demon strated frequently in the civil wars of Africa and Asia, has been the prolongation of many internal wars fuelled by legally permissible external support for an unpopular government and illegal but morally endorsed external support for an oppressed group. 
claims of cultural exceptionalism, religious fundamentalism, economic inequalities, and environmental degradation have the capacity to generate both interstate and intrastate conflicts.

The potency of these putative conflicts has increased as the everincreasing velocity of global communications and transportation nelworks has made it easier to access, participate in, and influence the outcomes of the conflicts. The proliferation and affordability of new communication and transportations technologies, coupled with those of powerful but miniaturized weaponry, and the privatization of sociopolitical causes mean that states no longer monopolize (if they ever did) the destructive capacity to wage wars. There is thus a massive disconnect between an international order built around the regulation of interstate behavior and the contemporary reality in which threats to the system may arise just as readily from non-state (or at least non-governmental) as from state behavior.

In this climate, how should threats be analyzed? Can the system continue to deal with threats as flowing primarily from state behavior, with the state being held derivatively responsible for the conduct of non-state actors that are presumptively subject to state control, or should the system confront directly these non-state sources of threat to the system? In addressing these threats, should continued primary reliance be based on persuasion, or does the efficacy of responses to these threats demand more actively coercive measures? And how are the costs of coercion to be weighed against the efficacy of the responses that

5: they generate? These questions, it seems to me, form the backdrop against which to view the High-Level Panel's proposed reforms to the system's assessments of and responses to anticipated threats to the system of collective security that the institutions of the United Nations have been crafted to realize.

\section{The High-Level Panel Report's diagnosis}

The twenty-first century started with a lot of optimism, at least among the decision makers whose views and outlooks determine international relations. Some of the more horrendous examples of warfare in the postSecond World War era had taken place in the 1990s, predominantly in the peripheral societies of Africa and the Balkans. African wars, waged in the backwaters of economic power and military might, and with handme-down weaponry, were generally not treated as implicating the kind of serious threats to international stability that had been the standard focus 
of collective security concerns. ${ }^{5}$ It required the unusual cataclysm of genocide, or a multinational confrontation in an especially resourcerich country such as the Democratic Republic of the Congo (then known as Zaire) for international society, outside of the continent itself, to become especially perturbed. The wars in the Balkans, waged in an arena that had become a persistent and perennial source of conflagrations among European empires, caused a good deal more consternation. But even there, the Great Powers, restrained by a history of accumulated errers-and uncertainties-as-to-the-transference of those experiences into the management of the fluid world of the 1990s, initially hesitated and equivocated as to the nature and scope of international intervention.

The management of events in the Middle East furnished a lodestar. The chief pariah state of the region, Iraq, was effectively brought under the thumb of the Security Council, which used its Chapter VII powers to rigorously enforce a thoroughgoing sanctions regime. In the Balkans and in Africa, the Security Council was seen to have learned from the mistakes of the 1990s and to have become a more effective body, highly interventionist in wrestling with the political disorders and human rights violations evident in what had come to be termed "failed states." To be sure, the conflicts between Palestine and Israel remained far from being resolved, and the Security Council had been divided over NATO's war in Kosovo; but even in those situations, the disagreements had not led to the sort of vituperative clashes between the big powers that a decade earlier would have been expected as de rigueur.

All in all, as the new century began, the United Nations sysfem, largely under the direction and control of its most prominent member and sole superpower, the United States, seemed poised to establish aworld governance system that could effectively herd, tame, and check the proclivities of nation states to insist on their right to act independently of any binding supervisory authority. It seemed this new regime could be held together through the affirmation of core neoliberal principles, notably those of "democracy," "human rights," "rule of law," and "free markets."

This euphoria over the existence of an allegedly effective international "legal" order contrasted sharply with the apparent incapacity of the

5 The massive European wars of the post- 1848 world, ranging from the national conflicts among the Germans and the French to the proxy colonial wars of the English, French, and Ilalians and the proxy ideological wars of the United States and the Soviet Union, involving, as they invariably did, reasonably organized interstate armies, were quintessential examples of what the international system had in mind when it spoke of "threats to collective security." 
system during the first thirty-five years of its existence to come anywhere close to the high aspirations for a just, peaceful, and ordered world that had been so eloquently articulated in the founding document of the United Nations system. ${ }^{6}$ The launch of a permanent International Criminal Court, the flaming-out of the much-dreaded " $y 2 k$ " catastrophe, the remarkable economic recoveries from the Asian and Russian contagions, the seemingly unstoppable boom in financial markets across the globe, successful development of democracy in Central and Eastern Europe, exemplary "non-racial" politics of South Africa, the touted universal acclaim for "human rights," and the sense that we all now marched to a single drumbeat, all gave a glorious tinge to the commencement of a new decade.

So, when heads of states and governments from around the globe gathered in New York in 2000 at a "millennium" summit, the focus was on the limitless future possibilities for humankind, rather than on reconstructing a demoralized civilization from the ashes of its self-destruction, as it had been in 1945. These leaders could focus on the ideals of "preventive diplomacy," "millennium development goals," "primary education," "nation-building," "sustainable development," the environment, economic development, and similarly broad agendas, rather than confront the messiness of specific regional crisis, or address the creaky machinery of the international system.

In particular, the 2000 conference could afford to suspend addressing the numerous calls for reform of the system that had emerged following the collapse of the bipolar world system. These calls in large measure - sould be (at least temporarily). dispensed withrbecause of the unchallenged dominance of Western ideals, intorests;institutions;iand concerns in the corridors of power. The seeming: unassailable position of the United States during the 1990 s effectively converted Western preferences into global policy. International agreement seemed not to be necessary because Washington could be expected to decide for all.

Three years later, however, international society faced a quite different landscape. The euphoria and triumphalism of "peace enforcement" was stalemated (if not checked) by the costs of nation-building. The efficacy of the neoliberal economic order, which had in part underwritten the unassailable position of the West in the 1990s, had been frayed by numerous financial crises, first in the so-called "emerging markets," and then in the dominant capital markets of North America and Europe. The confidence of the "sole superpower" in its ability to direct

"See, e.g. Preamble to the Charter of the United Nations; see also Article 1 of the Charter. 
the affairs of the globe had been shaken dramatically by the September 11,2001 attacks on symbols of its financial and military prowess. Notwithstanding the sympathy generated by those attacks, the confidence of much of the world in the leadership capacities of the United States in turn had been undercut by the shortsighted unilateralism that underpinned many of the responses to those attacks. Most consequentially, and partly as differing responses to those attacks, the Great Powers vigorously and vituperatively disagreed in public about the role- of the UN-Sectrity-Gouncil-in-bringing Iraq to heel. In particular, these powers, whose self-confident exercise of authority in the $1990 \mathrm{~s}$ had transformed the United Nations Security Council into a forceful baton-wielding orchestrator of international law and politics, now disagreed among themselves as to the appropriate steps for compelling Saddam Hussein's Iraq to abide by longstanding Security Council decrees. Outmaneuvered by France, the United States and the United Kingdom, with minimal pretext of legality, dispensed with demands for Security Council benediction of the invasion and overthrow of the government of a member state of the United Nations system. In the acrimony that followed, a re-elected Secretary-General, whose organization had just won the ultimate accolade - the Nobel Prize for Peace - felt sufficiently emboldened to appoint a panel to revisit the long-overlooked demands for reform. The High-Level Panel Report was the result.

Given the rapid and kaleidoscopic changes in the moodsand realities of international society just described; one cañnot help but be empa-: thetic to the daunting task faced by themembers of the Panel. To be sure, they shared the attribute of all being drawn from the most privileged cadres of their national socteties; and they were of necessity committed to multilateral internationalism. Yet they had to give voice to the claims and interests drawn 'from highly điverse socioeconomic and political cultures, and to do so through complete consensus. It's hardly surprising, then, that the Report at best is an amalgam of ideas that are held together only by the most elastic of principles. The Report proclaims that:

individual sovereign stales whose role and responsibilities, and right to be respected, are fully recognized in the Charter of the United Nations must form the backbone of any reform to collective security. But threats recognize no national boundaries... No State, no matter how powerful, can by its own efforts alone make itself invulnerable to today's threats. And it cannot be assumed that every State will always be able, or willing. 
10 meet its responsibility to protect its own peoples and not to harm its neighbours.'

What constitutes a threat? The Panel's working definition is "|a|ny event or process that leads to large-scale death or lessening of life chances and undermines states as the basic unit of the international system." These are grouped into six clusters: (1) economic and social threats including poverty, infectious diseases, and environmental degradation; (2) interstate conflict; (3) internal conflict, including civil war, genocide, and other large-scale atrocities; (4) nuclear, radiological, chemical, and biological weapons; (5) terrorism; and (6) transnational organized crime."

In evaluating the Pantel's Report, it must be acknowledged that it identifies genuine and persistent problems with which contemporary humanity must wrestle. To acknowledge the existence of problems, however, is not the same as treating those problems, mutatis mutandis, as threats to collective security. Comprehensiveness is clearly the watchword of the Report, but it might also be its primary shortcoming. It suggests that all threats are of equal weight, and in doing so, it avoids the hard task of providing grounds for prioritizing the expenditure of the surely limited resources available to the system. Moreover, this grab-bag approach avoids having to confront the possible trade-offs that may exist among threats, and between threats and prescribed cures. What relationships, for example, may exist between poverty, internal conflicts, and téryorism; and does addressing one or the other of these threats increase

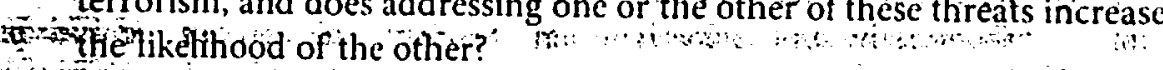

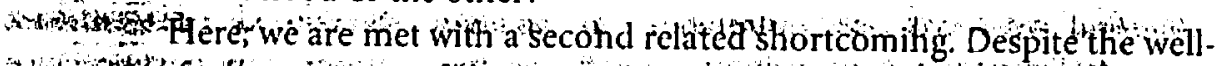
atrafted'arguments of the Report, and the volumes of back up tata, the criteria for the selection of purported particular threats are far from being transparently principled. To be sure, in virtually any circumstance, interstate warfare and genocide self-evidently implicate the likelihood of large-scale death and the lessening of life chances and clearly pose challenges of a collective nature to international order; but such clarity of threat (using the Report's own definition) is surely less evident in cases of terrorism or transnational organized crime. This is not to argue that these latter problems should not be of international concern, but what elevates them to more international solicitude or concern than, for example, "socio-economic discrimination" or inadequate access to

\footnotetext{
High-l.evel Panel Report. Sỵopsis, p. 1. * Ibid. Part 2 Sỵnopsis. p. 23. " Ibid.
} 
mental health? But the point of this introductory chapter is not to take issue with the specific diagnosis of threat (other chapters in this collection will do so), but to present a prism through which the Report as a whole should be looked at.

A third set of difficulties with the diagnosis presented in the Report relate to what might loosely be termed a deficit of causal linkages. As the report properly observes (in the context of the legitimacy of the authorization of military force as a response to a perceived threat), appropriate consideration

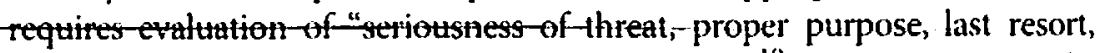
proportional means and balance of consequences." (And to these might be added capability and intention.) No less would seem to be demanded in evaluating whether an event or process constitutes an appropriate threat meriting collective response. Generalized or diffused poverty, for example, may generate a materially different type of threat to collective security than does squalor within a refugee camp. Similarly, it can hardly be doubted that the nature of the threat posed by HIV/AIDS is likely to differ materially from the deliberate use of a virus as a biological weapon in warfare. Along the same lines, the likelihood that an event or process constitutes a threat surely depends in no small measure on the likely immediacy or fanciful nature of the event. How remote is the capacity of the event or process to generate large-scale deaths? What are the intentions of those capable of generating the condition that is deemed potentially to constitute a threat, or their capacity to exercise control over its actualization? The dynamic realities of life mean that what might appear as a threat today may in retrospect prove to have been. nothing of the sort. The unly way. of avoiding such false positives is in the rigor of analysis; a state of affairs that unhappily is thandicapped by the demand for consensus among a politically tesponsive group warking in an environment of rapid and kaleidoscopic change. Just as international society cannot afford to be complacent about potential dangers, fear of the poorly understood "other" should not be allowed to form the basis for policy responses to purported threats to collective security. The more generalized and diffused the definition of "threats," it seems fair to point out, the more likely it is that the nature and sources of those threats are being exaggerated.

One last discrepancy between principle and analysis bears pointing out. While the members of the Panel clearly side with those international lawyers who continue to see the project of international relations as revolving around the state, they also accepted that threats to international security increasingly arise from non-state actors. The logic of this analysis,

1" Ibid., Part 3 Synopsis, p. 61. 
however, is barely followed through. In evaluating the responses to putative threats to collective security, the Panel Report continues to be primarily monochromatic, focusing almost exclusively on state action. There is thus a disjuncture between diagnosis and prescription.

The purpose of this chapter, however, is not to skewer the High-l.evel Panel for the rigor of its analysis. Indeed, as I have already suggested, given the international climate in which it functioned there is much to be favorably said for the conscientiousness with which it approached and discharged its assigned tasks. Rather, in presenting these shortcomings, I want to indicate some of the handicaps the Panel faced in articulating preventive measures. It is the efficacy of these measures, and more particularly, the extent that the measures may themselves sharpen or reinforce the threats and challenges identified by the Panel that is this chapter's focus.

\section{Post-Cold War collective prevention of threats to international security}

The reason for identifying threats to international security is of course to permit the international system to fashion responses - preferably collective in character - to those threats. An advantage of the traditional view of a threat as being essentially one that involved a transborder threat to the peace and security of a member state of the United Nations is that it provided a reasonably objective yardstick with which both to gauge the threat and to detcrine those actions that would be responsive., Where a member state felt threatened, it always had the option to deal directly through non-coercive action (for exanple negatiations and perhaps even primary economic boycotts) with the source of the threat if in fact the threat materialized, the member state, under Article 5.1 of the Charter, had the legal right to employ limited force to address it. But a member state did not have to wait until the threat materialized in order to request the auspices of the international community to address what it perceived to be a threat. Under Chapter VI of the Charter, a member state could always invoke the good offices of the system (especially the Security Council) to address the threat. ${ }^{11}$ These two institutions had a panoply of means that they could resort to, including negotiations,

"See generally Uniled Nations Charter, Articles 35-37. On the use of "good offices," see, c.g.. Alys Brehio, "Good Offices of the Secretary-General as Preventive Measures," 30 NYUl Int' L. \& Pol. 589 (1998). For case studies addressing the effectiveness of UN "good offices" missions, compare: Claire Palley, An Intermational Relations Debacle: The 
conciliation, recommendations, and moral suasion to avert the looming conflict. In the event of failure, the problem could be escalated and under Chapter VII, the Security Council was fully empowered to take coercive measures, including the use of collective military force to bring a determined wrongdoer to heel. ${ }^{12}$

One of the shortcomings of the United Nations system between 1945 and 1990 was the hesitation with which it resorted to the use of the Chapter VII powers. That hesitation grew out of the polarized politics of the Cold War. The collapse of the-Soviet- Inion-as a reflexive rival center of power inaugurated a new era in which the Security Council was afforded the opportunity to weigh on their own merits claimed threats to collective security, and to take preventive measures in a dispassionate manner. But the manner of the exercise of these powers over the next decade and a half disclosed two obvious flaws in such optimism.

In the first place, the hoped-for objectivity proved to be forlorn. The decision as to the exercise of Chapter VII powers depended almost exclusively on the political preferences of the United States; preferences that are configured by the country's domestic interest groups rather than any sense of a shared common wellbeing for the so-called "international community." Secondly, the absence of counterweights in the Security Council meant that any perceived threat was almost always dealt with under the coercive authority of Chapter VIII. Use of the more conciliatory instruments of Chapter VI atrophied. The resulting gravifation of power to the Security Council laid bate its undemocratic structures, and precipitated questions of its legttimacy: Mány of these questions could and were avouded unitil the sthanp disagreaments first over Kosovo and later over haq made ignoring them less and less tenable.

A consequence of the reliance on Chapter VII was the need to flesh out its preventive tools. In the aftermath of the Second World War, coercive military force had been contemplated as a last resort, and the United Nations Charter extensively provided the criteria for such use of military force, as well as the means and manner for its organization. Actual Cold War practice had rendered these charter provisions effectively moot. In the wake of the return to the exercise of power under

UN Secretary-General's Mission of Good Offices in Cyprus. 1999-2004 (Oxford: Hart Publishing, 2005) and David J. Ludlow, "Preventative Pcacemaking in Macedonia: An Assessment of UN Good Offices Diplomacy," Brigham Young University Law Revicw 761 (2003).

12 See generally United Nations Charter, Articles 39, 42. 
Chapter VII, little of precedent could be called upon. Much of the subsequent behavior was dictated as much by ad hoc considerations of cost and expedient politics as by any principled resort to Charter provisions or established legal rules.

Coercion by military force can be both financially and politically expensive. Early Chapter VII operations in Iraq. Somalia, Haiti, and the Balkans brought these realities home. The system adapted quite readily. Coercion through economic sanctions became the more favored tool. This approach had two radical effects that must be considered in any evaluation of the treatment of sanctions in the High-Level Panel's Report. In the first place, precisely because sanctions, unlike military force, impose relatively insignificant costs on those who seek their use, the tendency to advocate their use is much greater. Secondly, because their effects are concentrated on weak and vulnerable societies, their use magnifies the distributive inequalities in the system and the troubling issues of legitimation raised by the unrepresentative structure of the Security Council. In what follows, 1 explore how the High-Level Panel Report confronts these two questions. I then go on to suggest alternative responses to these twin deficits of accountability and legitimacy.

\section{Sanctions and collective security}

Dr. Jeremy Farrall, in his contribution to this volume, has thoughtfully canvassed the occasional strengths and many weaknesses of, the iniple $\ddot{z}_{-}, \ldots$ in amentations of the UnitediNations sanctions:regines: ${ }^{13}$ I do not: wishom where:to rehearse manyof his cogently, made pointsy what d do wanto todo in is to examine the use of sanctions as a systemio poliey for furthering collective security. Under such an inquiry, enforceability and efficacy of specific regimes, while relevant, is not the subject of study. Rather, the -primary theme that I wish to pursue here is the value of sanctions as instruments of policy, both in terms of the specific justifications for them advanced by the High-Level Panel (and other members of the international intelligentsia) and the overlooked discordant notes that sanctions may present for an order based on the principle of collective security. In so doing I am interested in the resort to sanctions not simply as a coercive

13 See leremy Farrall. "The World Summit Process and UN Sanctions Reform: Between Rhetoric and Force," below, Chapter 9; Jeremy M. Farrall, United Nations Sanctions and the Rule of Law (Cambridge: Cambridge University Press, 2007). 
policy tool in and of itself, but for its symbolic value in the international system's pursuit of collective security. ${ }^{1.4}$

The basic argument for economic sanctions (and by "sanctions," we almost always mean "economic sanctions") is straightforward. ${ }^{15}$ It is seen as a middle point between doing nothing and using military force. ${ }^{16}$ The creators of the United Nations system carefully orchestrated the role of the Security Council as a graduated ratcheting-up of the General Assembly's non-binding recommendations to Security Council recommendations-under Ghapter-VHand then ultimately binding action under Chapter VII. They also provided for a graduated and symmetrical response under Chapter VII from a simple finding and declaration of threats to or breach of international peace and security under Article 39, to the use of sanctions under Article 41, culminating of course in the outright use of force under Article 42.

On its face the analysis for determining the legal legitimacy of a sanctions regime would appear to be fundamentally no different from that for deciding upon the use of force under Chapter VII. Upon closer scrutiny that syllogism exhibits its failing as an analytical tool in matters of policy. Because of the substantial costs that it entails, the use of force is rarely employed as a policy solution. Specifically, the use of force requires that member states be willing and able to raise and finance armies. Furthermore, it requires that the international system be willing to justify the all-too-visible consequences of waging war. ${ }^{17}$ There are thus

(r)
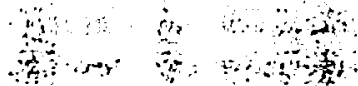

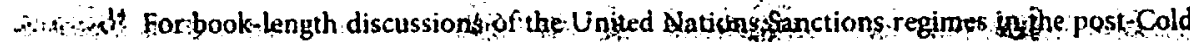
war world, see Farrall, United Nations Sanctions and the Rule of Law; David Cortright and Gcorge A. Lopez, The Sunctions Decade: Assessing in Strategiestn the 1990 s (Boulder, Colorado: Lynne Rienner, 2000). ind

19 The United Nations sunctions ostensibly have come in several varieties including diplomatic isolation, travel bans; and outright refusals to deal. See, e.g. Farrall, United Nations Sanctions and the Rule of Law. These on their face are either obviously counterproductive, or can be seen as being effective only in the light of their economic effects. Further, use of economic sanctions under Chapter VII should be distinguished from the imposition of arms embargoes. The latter legitimately can be seen as working in pari passu with coercive military force. For this reason, the arguments presented below are intended to be considered within the context of economic sanctions rather than of embargoes on the shipment of arms and ammunitions into areas in which the existence of conflict is determined by the Security Council to constitute threats to international peace and security.

16. See, e.g.. High-Level Panel, para. 178: See also Kofi Annan, In Larger Freedom: Towards Securit): Development and Human Rights for All, A/59/2005 (March 21, 2005).

17 Difficulties in staffing UN peacekeeping efforts illustrate this point. To avoid these difficulties, the Securily Council has simply either contracted out war waging under 
substantial extralegal checks on the use by the Security Council of force as a policy tool.

Before accepting resort to economic sanctions as the lesser evil of two legally permissible tools, it is worth reflecting on the extent to which similar extralegal considerations may influence - whether for better or for worse - decision making regarding the use of sanctions. It is unfortunately an issue that has not received much attention. The instinctive understanding being to believe that since sanctions seemingly pose lesser intrusiveness or apparent social costs than the outright use of force, they must necessarily be preferable. But sometimes a supposedly lesser evil is not necessarily preferable. ${ }^{18}$

As a jurisdictional matter, the Security Council's legal authority to impose economic sanctions is triggered only by a determination that there exists a "threat to the peace, breach of the peace, or act of aggression, and that sanctions are necessary to remove such related threats to international security, or to maintain or restore international security." ${ }^{19}$ These determinations are lodged exclusively in the Council itself. Neither the Charter nor any extant authoritative text or interpretative decisions judicial or otherwise - have furnished any persuasive, let alone binding determinations of the scope of this jurisdictional verbiage. ${ }^{20}$ One is thus forced to rely on reading the tea leaves of the highly politicized and

Chapter VII, as in the case of the "Gulf War" (see Security Council Resolution 678), or stood on the sidelines while the war is waged only to provide its imprimatur after the war (conipare Securify Cduncil Resolution 1244 (afler the Kosovo Wat), and security Council Resolution 15I /(following the US-led invasion and occupation of itaq)).



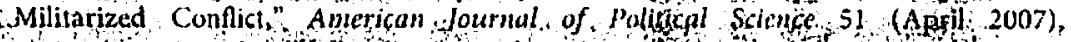
pp. 415-431 (empirically demonstrating that resori tojsanctions often does not obviate the use of military force).

UN Charter, Article 39.

20. The extent to which these determinations may be subject to dispositive legal rules has generated much discussion. See, e.g., Prosecutor v. Tadic, Case No. IT.94-1-T. Opinion and Judgment, May 7. 1997; see also Questions of Interpretation and Application of the 1971 Montreal Convention Arising from the Aerial Incident at Lockerbic (Libya v. UK; Libya v. US). Provisional Measures (Orders of April 14, 1992), ICJ Reports (1992), p. 32 (Judge Shahabuddeen, separate opinion), p. 64 (Judge Schwabel, Separate Opinion), p. 65 (Judge Weeramantry, dissenting opinion). Compare Thomas M. Franck, "Powers of Appreciation: Who is the Ultimate Guardian of UN Legality?," 86 AIIL 519 (1992) (analogizing the ICl's authority to review the "political" decisions of the Security Council to the famous US case of Marbury v. Madison, which enshrined the doctrine of judicial review of legislative and executive actions within US domestic law). An interesting development with potentially far-reaching possibilities for bringing under review and ultimately cabining Security Council exercise of coercive power is the willingness of domestic and regional courts to review for consistency with domestic law the exercise of 
generally far-from-consistent practices of the Council. Even under the most sympathetic of readings, the inescapable conclusion one arrives at after reviewing those practices is that the Council's behavior with regard to determinations under Chapter VII is that it has been unprincipled. ${ }^{21}$

The sole predictor of whether the Council would deem a situation to constitute a threat to international peace and security often has been (and, for structural reasons, likely will continue to be) the internal politics of the five permanent members, and most especially those of thestion-of "collective security" and the concomitant invocation of economic sanctions are thus dictated by the need to satisfy the demands of interest groups within the domestic politics of the permanent members of the Council. ${ }^{22}$ And here, we encounter the first difficulty with the seemingly intuitive presumption that resort to economic sanctions invariably should be preferred to military action.

The use of force demands a much more extensive mobilization by a state of its resources than almost any other decision that a state makes.

power by governments that are subject to their judicial supervision, even when the claim of such governments is that they are acting at the command of the Security Council. See. e.g., ECI Judgment 0904|1] (2008) (invalidating EU Commission Regulations that sought to enforce Security Council Resolutions that required the freczing of the assets of alleged supporters of terrorism without providing such persons any meaningful opportunity to challenge their designation as such). Compare Munaf v. Geren, 128 S. Ct. 2207 (US Supreme Court, 2008) (bolding that United States citizens detained by United States soldiers purportedly acting under the authority of the "Multinational force in Iraq" nonetheless retain the right to seek ricyie of their deterition despite the fact that

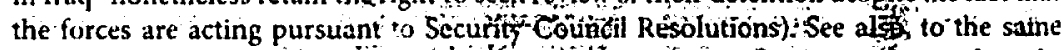

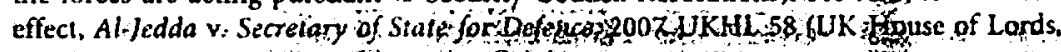
2007).

2 Dr. Farrall presents this discrepancy in the tangage of the rule of lay of by which he means the "use and abuse of power"-within prescribed boundaries. See firrall, United Nations Sanctions and the Rule of Law. p. I1. For reasons that I explain below, I do not subscribe to the view that the issues are essentially those of the ability of permanent members of the Security Council to interpret and abide by legal rules, even if one assumes that unavoidably political decisions can be so cabined. The difficulties in my view are structural, not questions of intent or good faith obedience to rules.

22 Neither space nor the subject matter of this chapter permits substantial elaboration here of this claim, but it is my contention that the claim is amply supported by any dispassionale examination of the otherwise counterintuitive treatments under Chapter VI of the Arab-Isracli conflicts, when contrasted with the treatments under Chapter VII of Libya, the Darfur civil war in the Sudan, and Liberia. And while the motivations for Security Council actions regarding the Democratic People's Republic of Korea and the Islamic Republic of Iran may at first blush not fall within this framework, the specific provisions of the Resolutions clearly have been dictated to respond to the internal politics of the member states rather than to any overarching interest of the international system. 
This is because the modern state in large measure owes both its creation and destruction to warfare. ${ }^{2.3}$ Governments, whatever their nature, do not therefore lightly undertake measures that entail the use of force. ${ }^{24}$ With regard to such decisions, a government, whether democratically elected or not, ultimatcly will have to account to its entire citizenry; for after all, in choosing to deploy force, it is gambling with the welfare (if not outright existence) of the entire society, not simply those of a subsection.

Given the structure of the United Nations system, this hesitancy in state behavior is transmitted to that of the system as a whole. Lacking any armed force of its own, any decision to resort to force by the United Nations system is entirely diclated by the willingness of individual members to furnish that force. ${ }^{25}$ In this sense, the notion of collective action (seemingly embedded in the notion of "collective security") is at best deceptive. In reality, Security Council action authorizing the use of force under Chapter VII is in fact a statement on behalf of a handful of member states that deem the purported threat sufficiently weighty to undertake a mobilization and commitment of their national resources to the specified cause. Critically, the decisions of this handful of states are driven as much by the dynamics of their internal politics as by any global view of the welfare of international society. It is therefore hardly surprising that, putting aside the so-called "peacekeeping missions," the United Nations system has resorted to the collective use of force only very sparingly. Indeed, only two instances - the Korean War of 1950 ; and the "first"

Resart to sanctions on the other hand, does not itequing the mass nojobilization of national resources. Their effects on societies are discrete and often insular. Properly calibrated, those êfects cantin fact to isolated and walled off from much of society or at least those elements of society with the greatest capacity to compel governments to account for their policies. In imposing sanctions under Chapter VII, the Security Council, far from simply articulating or giving its imprimatur to a decision taken by national governments, is in fact directing that national governments

23 See, e.g., R. Harrison Wagner, War and the State: The Theory of International Politics (Ann Arbor: Universily of Michigan Press, 2007).

2" Given humankind's history, this might seem counterintuitive; but it is surely the case that in contemporary society, and given the destructive consequences of war, so-called "wars of choice," have become the exception rather than the rule; a lesson that cven the most powerful country in the world is beginning to appreciate.

${ }^{25}$ See United Nations Charter, Articles 43-48. 
adopt specific policies to isolate and punish the miscreant. Put in straightforward terms, while the coercive use of force under Chapter VII essentially is a ratification by the international system of national policies, the imposition of sanctions is a directive about proper national behavior to sovereign states. Contrary to conventional teaching, then, the latter is therefore undoubtedly a much more intrusive involvement by the international system in the affairs of member states.

It is commonplace to point out that by acceding to the Charter and its provision in Article 25, member states thereby consented to the authority of the Security Council to dictate policies to them under Chapter VII. T'he arguments just advanced do not necessarily dispute the legal merit of such a position. The analysis here presented nonetheless challenges the sufficiency of such a purely formalistic approach in evaluating the legal and policy choices available to the Security Council under Chapter VII.

In reflexively treating economic sanctions as the lesser interference in the affairs of a state, the High-Level Panel (and indeed most other commentators) simply and unquestioningly accepted the rather superficial proposition that the use of force almost always entails greater intervention than nonmilitary coercive measures. That presumption is tenable only if one ignores the other checks that attend the willingness of states to employ force. The value of the comparison, in terms of intrusiveness, between actions under Article 41 and those under Article 42 requires one to consider the extent to which the implementation of Article 42 is taken in tandem with that of Article 43. Singethe United Nations system has never satisfied Article 43 s requirement that it raise, finance and command its ownarmy, but instead has engaged essentially in unsupervised outsourcing of the use of coercive forcenthe the pationship between Articles 41 and 42 has been turned on its head. The topcceptance of Article 25, it can be argued, presupposes a good faith implementation - of Chapter VII which would include compliance with the procedures andstructures laid out in the Chaprer.

It is evident that resort to sanctions under Chapter VII is driven in no small measure by the fact that it can be precipitated by an active and vocal minority acting below the radar of transparent politics. It is equally evident that given this foundation, any sanctions regime will remain effective only so long as its effects are confined and isolated. This is true both with regard to effects on the countries being asked to withdraw their goods and services, and, less obviously so, on the society being boycotted. In countries that are asked to impose sanctions, widespread effects similar to those incurred in waging a war clearly will precipitate 
the sort of searching inquiries that typically attend military conflicts. The most obvious criticism in such countries would be the unrepresentative character of the decision-making process. Moreover, where those effects are socially or economically significant, there will be a strong pull to employ subterfuges to avoid or evade the sanctions. The more pervasive the avoidance attempts, the more morally unacceptable the sanctions regime will become. lacking initial broad support, the sanctions ultimately will likely collapse. Two examples should suffice to support these claims.

Consider first the international system's imposition of economic sanctions on Libya following that country's refusal to hand over two of its citizens accused of terrorism for trial in the United States or the United Kingdom. "Those sanctions initially were imposed on a discrete service air transportation in and out of Libya - and a quintessential arca of international security concern: the sales of arms and munitions. ${ }^{27}$ These were sufficiently narrow in scope and related to an area of acknowledged Security Council jurisdictional competence that, although adopted with the barest of the required majority, there was initially little overt opposition from within the Security Council. Subsequently, the sanctions were expanded to embrace the supply of the infrastructure and goods that underpinned airline travel and the production within Libya of crude oil. ${ }^{28}$ This almost immediately generated opposition from members of the Organization of African Unity. ${ }^{29}$ As long as there was a surplus of the supply of crude: oil in the world market (a state of raffairs that was dinacteristic of the 1990s); the effects of the sanctions on the societies bing askedto impose them were relatively shall and geverallylocalized. In the beginning of the new century, however, the wortd market for oil tégan to change As global oil dermand outpaced supply, Libya's neigh: bors, most of them thirsty for Libya's relatively cheap oil to feed their fragile economies, began to feel the negative impact of the $U N$ Libyan sanctions regime. Economic woes, coupled with the ever-intensifying sentiment that prohibiting Libyans from being able to-fly safely to Mecca

20 See generally lan Hurd. Afer Anardy: Legitimacy and Power in the United Nations Security Council (Princeton: Princeton University Press, 2007), pp. 137-172 (arguing that Libya outmaneuvered the United States and the United Kingdom in deploying arguments about the legitimacy of the exercise of power by the UN Security Council).

27 Sec Uniled Nations Security Council Resolution 7.18 (1992).

2* Sec Security Council Resolution 883 (1093).

"9e Organization of African Unily, Resolution on the Crisis between the Greal Jamathiriya and the USA, UK, and France, OAU Res. 1525 (1994). 
for the Haj was imposing an unnecessary hardship on a civilian population trying to practice its religion, caused African and Middle-Eastern governments to rethink their hitherto passive acceptance of the Security Council directive that they boycott Libya.

Although starting gradually, as the new century began there was a groundswell of opposition to sanctions against Libya from African and Middle-Eastern countries that were bearing the brunt of a sanctions regime in whose creation they had had virtually no input. Disregard for the sanctions regime increased in frequency, and the writing was on the wall. The countries that had espoused and promoted the sanctions regime eked out the best compromise they could under the circumstances. The termination of the sanctions regime, far from endangering international security, may have enhanced it. The United States, the United Kingdom, and Libya engaged in active bilateral negotiations that have in fact resulted in substantial economic interactions and reasonably friendly political relationships among these countries. Indeed, the United States now hails Libya as having contributed substantially to the US-led global antiterrorism campaign, and to global efforts to resolve the thorny political and human rights problems in Darfur. ${ }^{30}$

The imposition, continuation, and management of sanctions by the Security Council on Iraq following its defeat in the first Gulf War further illustrate some of the perversities that flow from a simplistic mindset that endorses sanctions as an acceptable intermediate tool between blithe acquiescence in wrongdoingand incurring the costs of full fledged war. The original sanctions reginethad ben instituted as a mean to avoiding war. ${ }^{31}$ Notwithstanding its forige to prexent the war santions nonetheless retained approbationifirstas a means of coercing compliance with the imposed terms of Iraq defeat, and subsequently as a less belligerent alternative to an international humanitarian intervention to behalf of the Kurds of Northern Iraq and the Shia population in Southern Iraq."

The unsuitability of sanctions for these tasks soon became evident. Sanctions could not succeed as a means of coercing Iraqi compliance with the terms of the 1991 truce in part because different members of the Security Council had different views as to what would constitute

30 Jay Solomon, "Second Thoughts: Libya Sours on US Ties Amid Boom in Economy," The Wall Strect Joumal (May 16, 2008), p. 1.

${ }^{31}$ See, e.g., UN Security Council Resolution S/RES/661 (1990). August 6. 1990; UN Security Council Resolution S/RES/665 (1990), August 25, 1990; UN Security Council Resolution S/RES/674 (1990), October 29, 1990. 
adequate compliance. Although Resolution 687 purportedly articulated the relevant terms, it was quite obvious that for the most important member of the Security Council, the United States, nothing short of regime change would do. ${ }^{32}$ For many, whether motivated by international legal norms or internal domestic interests, the use of Security Council sanctions power for such an unspoken end was not only improper, but it directly threatened a core political norm of the system, namely that the international system ought to refrain from direct involvement in shaping the domestic political order of member states of the Organization.

The challenge to the legitimacy of sanctions was not simply ideological or philosophical. Those attributes that rendered the glib resort to sanctions so appealing also undermined their effectiveness. One reason why many in the West found sanctions so acceptable was that their infliction of pain could easily be masked. Unlike the televised "turkey shoot" of Iraqi soldiers that had undercut the 1991 march to Baghdad, sanctions were seen as more likely to succeed precisely because they operated away from the apertures of television cameras and would, therefore, be less likely to eljeit outrage from the squeamish, liberal middle class. By 1996, however, the real human costs of sanctions were becoming all too evident. Five hundred thousand visibly diseased and malnourished Iraqi children no less cogently raised the morality of the cost-benefit trade-offs in the use of sanctions than had footage of the massacres along the highways of death in the Gulf War. ${ }^{33}$

These direct human costs were amplified bycormuption both finan-: thaland potitical - engendered by the remarkably opapue administration fof the sanctions regime. Stories abounded of abiand ant and for the most part inserutable diplomatic and political sheriaungans in the so-called Committee 660 of the Security Council whichiwas atharged with effecguvely unreviewable power to: administer all aspects of the sanctions. ${ }^{34}$ is $\cdots \cdots$......

92 This sin

This was the position of the United States government. See, eg.. the Iraq Liberation Act, H.R. 4655. Public Law' 105-338 (10/31/98).

${ }^{33}$ The symbolism of a television interview on America's premier television news magazine show "60 Minutes" by the show's first female reporler of the United States' first female Secretary of State, Madeleine Albright, in which the latter indicated that the sulferings of Iraqi children was of little moment, illustrates the undermining of the moral legitimacy of sanctions. In one of her most notable and notorious statements, Mrs. Albright dismissed claims that 500,000 Iraqi children may have died as a result of United Nations sanctions by characterizing it as a "price [that is] worth it" for bringing Irag and its then leader. Saddam Hussein. to heel. Interview with l.esley Stahl. CBS, "60 Minutes." (May 12, 1996).

3 See, e.g. Joy Gordon, "Cool War," Harper's Magazine, November 2002. 
The disclosure of the pervasive financial corruption within the sanctions regime took a while to receive confirmation, but its existence was hardly doubted. ${ }^{35}$

These failings, which differed from those experienced by other sanctions regimes only in their magnitude, would nonetheless have been overlooked but for two additional failings. First, the utter failure of sanctions to obtain any of the sought-for objectives was simply too glaring to be ignored. 'The frequent use of military force by the United States and the United Kingdom-as-backup coercive measures showed the shallowness (if not outright falsity) of the claim that the international system was faced with an either/or proposition between military force and economic sanctions. While Iraqis were being subjected to the penalties of economic sanctions, United States citizens were also being asked to bear the cost of a low-intensity war for which the nation had not been mobilized. The ordering of a sustained bombing campaign by the President of the United States at a time when he faced likely impeachment for lying about his sexual escapades could not but illuminate the moral and political failings of the reliance on sanctions as a means of keeping Iraq in check.

Second, the weaknesses of the sanctions regime were magnified when, following the cessation of the bombings, both the United States and the Security Council appeared entirely at a loss as to how to follow up. Both meekly accepted Iraq's ordering out of the United Nations arms inspectors, who had supposedly been charged with monitoing Irig compliance with the terms of Resolution $6877^{36}$ Yet; the satietions


sanctions regime with no means for telling when they diogid be considered a success or a failure That dilemma ullustrated osigzificant and devastating challenge for the use of sanctions. No state ot society can remain in a perpetual state of siege. Military force thán' al least one important check on its use: namely that at some point, one side or both give up and sue for peace. Given the asymmetrical structure of sanctions, it is conceivably possible for one country to maintain sanctions for an

35 See generally the multi-volume Report of the Independent Inquiry Committee into the United Nations Oil for Food Program (The "Volcker committee"), available at: wwwiic. offp.org/.

3h Sec generally Scott Ritter, Iraq Confidential: The Untold Story of the Intclligence Conspiracy to Undermine the UN and Overthrow Saddam Hussein (London: Tauris, 2005). 
indefinite period of time. ${ }^{37}$ This was precisely what the Iraqi sanctions regime seemed to foreshadow.

It was thus hardly surprising that by 2002 much of the world had lost patience with the lraqi sanctions regime. As with the Libyan sanctions regime, many countries outside of the Western world were beginning to see Security Council sanctions less as a device for colleclive security and more as a means for punishing independent-minded governments that operated outside of the W'est's orbit. The L'nited States seemed to understand this and tried to alter the dynamics of the discourse by calling for "smart sanctions." Unable to obtain the requisite consensus, it ultimately chose the outright waging of war, and thereby gave the coup de grace to the sanctions regime.

Considering the above, a resort to sanctions should not be viewed with pacific equanimity. Sanctions may on their face appear as an attractive alternative to the use of force by a hegemonic Security Council. ${ }^{38}$.They certainly act as a salve to the conscience of humanity. But this alternative has its own - and by no means insignificant - costs. As evident from the brief discussion just presented, these include the following: First, there are the genuinely humanitarian and social costs that are disproportionately born by the poorest and weakest individual members of those societies that sanctions seek to ostracize from what passes as an international community of states. Second, like any politically induced regulatory regime, the administration of sanctions regimes invariably appears ato harbor the seeds for far-reaching corruption of the administering $\therefore=$ manghorities. Third; while it might be hopod that sanctions work in the in trateres of coercing the preferred behavion from those on whom they are atefimposed, there can be no assurance that they will so work thdeed, istotistory suggests otherwise. What seems indisputable is that when they do fall, the international political system is left with two bleak and equally unpalatable choices: to employ the force that sanctions originally were intended to avoid, or to capitulate in abject surrender to the detested evil. Perhaps these shortcomings can be ignored if the likelihood of sanctions succeeding is the norm rather than the exception. Notwithstanding the enthusiastic support of sanctions, there is in fact virtually no history

3: The United States has maintained a more or less complete boycont of Cuba for almost fifty years. Its boycott of North Korea has been longer, and its usc of sanctions against Iran has been ongoing for almust thirty years.

36 Compare losé E. Alvarez, "Judging the Security Council," 90 A/L I (1990); lose E. Alvarez. "Hegemonic International Law Revisited." $97 \mathrm{~A} / \mathrm{HL} .87 .3$ (2003.3). 
to support such optimism. Indeed, it is virtually impossible to come up with any instance in which sanctions can be said to have had unqualified success. ${ }^{39}$ These systemic shortcomings, although scrupulously avoided during discussions of sanctions regimes, are all too obvious to policy makers. Attempts to address them by such tactical changes of policy as those embodied in so-called "targeted" or "smarter" sanctions that aim to narrow the range of persons, products or services covered may reduce the interest groups that are affected, but they are unlikely to address the systeshertingsust diseussed.More-significantly, such expediencies are as likely to reduce the practical effectiveness of a sanctions regime as to improve their moral acceptability.

That the illusion of sanctions as an effective tool of collective security was so unquestioningly embraced by the hard-headed diplomats, politicians, academics, and statesmen of the High-Level Panel spcaks as much to the seeming absence of alternatives as to anything else. That the table is so barren of choices may be as much a testimonial to the failings of human imagination in the age of power and glory as it is to the triumph of idealism. What then is to be done? It is to this question that the concluding part of this chapter turns.

\section{Rethinking the concept of collective security}

The focus on the use of sanctions, it should be remembered, has been for the purpose of exploing gine of the several tools chosen by the High-

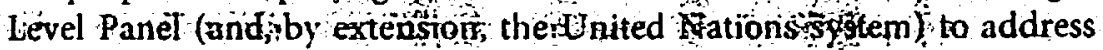
the demands forcollectives fecurity in the internationationder Although in thinking about sanctions and the other tabls available to the system the default approach is to ideraluate theit efficacy it should not be forgotten that it is just as improper to consider sanctions as an end, in and of itself, as it would be to think of the use of force in this manner. After all, the resort to sanctions, even if effectively applied, is already a statement about the failure of the system to provide the necessary security to at least some of those for whose benefit the system supposedly exists. Unfortunately, this tendency to substitute means for ends is all too

39 The example typically adduced in support of sanclions is its use against the apartheid system in South Africa. For a variety of reasons, the discussion of which is beyond the scope of and space permitted by this chapter, the example is inapposite. That the South African example has superficially underpinned the moral case for sanctions cannot be denied. The international system might do well, however, to treat it as sui generis. 
pervasive in contemporary thinking about international law. The costs that this tendency poses for international law should not be overlooked, and it is with some reflections on them that this chapter closes.

The collapse of communism at the end of the 1980s and early $1990 \mathrm{~s}$ offered liberal states an unparalleled opportunity to reshape the world order. The balance of power system that de facto had structured international relations during the Cold $W$ 'ar was swept away, leaving the scene open for the implementation of the collective security norms that had formed the foundations of the San Francisco Charter. Under the Charter, collective security was framed in two dimensions. On the one hand, it was assumed that there were interests common to all peoples and states and that, in the interest of peace and iustice, all member states of the United Nations system would strive for their realization."

Those transcendent interests were framed in unexceptionable terms; they needed to be because of the second feature of the Charter's conception of collective security. That feature assumed the existence of shared interests, but it was also grounded in the view that societies and their political orders can be and frequently are different. Coexistence, cooperation and collaboration, rather than assimilation or coercion, should be the operational norms of collective security. The implementation of collective security thus demanded a healthy respect by member states of the United Nations and the organization itself for those differences. ${ }^{41}$ This view that the concept of collective security requires bifurcation between transcendent ends and practical-means, between shared uniyersal goals articulated throughideliberation and consensus, on the one hand and implementation throughhighly restricted means on the gther, is embedded in the structure of thesystem, The diffusions of representa tions and power between the Genexal Assembly the Security Council, and the functional agencies (including the International Court of Justice) exemplified the cooperative contractarian-view of the maintenance of international order through the concept of collective security. Collective security, as envisioned by the Charter, was thus not a super-norm to be achieved at all costs. Rather, it was accepted under the San Francisco Charter as being viable only if the ends were shared, and the means achieved through cooptation and consensus.

The Cold War experience challenged the effectiveness of the system that had been thus created. The bipolarity of the conflict between

40 See Linited Nations Charter, Preamble and Article 1.

"See generally UN Charter. Article 2. 
Communist and market-based societies and the pressures put on so-called "nonaligned" states within the system undermined the claims of shared norms and frustrated the means for their realization. Indeed, far from resting on the concept of collective security, the international order of the Cold War seemed to be a reversion to the discredited balance of power arrangement with which both the League of Nations and the United Nations had been intended to dispense. Understandably, then, the triumphant liberal states of the post-Cold War order did not simply want to return to the originat interpretation of the San Francisco Charter. Adopting a posture that is perhaps innate in victors, they emphasized those ideals that were more consonant with their own domestic systems, and did so with little regard for their effects on societies that differed from theirs. 22 The search for universal justice rather than for peace was to be the defining goal, in the service of which guaranteeing the proclaimed rights of the individual, whether in the political or the economic sphere, was to be privileged over the promotion of the complex network of group interests that euphemistically is referred to as "self-determination." More controversially, coercion (by economic or judicial means, when feasible, but military force, when otherwise necessary) rather than cooperation and persuasion became the accepted means for achieving these ends.

The Security Council, whose enforcement powers had lain dormant, was the one preexisting institution that could be pressed in to service. It did suffer from one not insignificant shortcoming: its lack of representativeness of the peoples over whom itlorded lack of representativeness is af course not iti peoples over whom ition

(x) +40

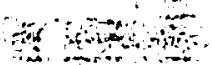

$+2$

42 One of the most egregiôis î

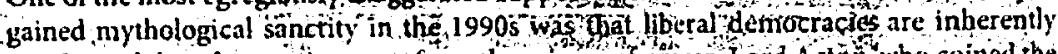
pacific, and therefore arejmmune from the misuse of poweryord Actong who coined the aphorism that "power corrupts absolute power corrupts absolately" was of course himself a denizen of a liberal democracy when those were indeed extremely rare. Both William Jefferson and John Stuart Mill were all too aware of the possibility that majorities can be tyrannical. Indeed, it is precisely to check the propensity for abuse of power even in a democratic society that foundational documents such as national constitutions and the United Nations Charter serve pivotal roles in constraining the potential for abuse of power. What is true about power relationships within the internal structures of liberal democracies is even more so when the governments of those democracies are not answerable to the people over whom they wield their power. In modern times, some of the most aggressive forms of European colonization and coercive subjugation of non-Luropean peoples were superintended by two quintessential liberal democracies: Victorian England and the Firench Third Republic. See. e.g. Anthony Anghic. Imperialism. Sovereignty and the Making of International Law (Cambridge: Cambridge University Press, 2004); Jennifer Pitts, A Turn to Empire: The Rise of Imperial Liberalism in Britain and France (Princeton: Princeton University Press, 2005). 
necessarily fatal; however, since the dominant post-Cold War liberal order had come to see democracy as the birthright of all peoples, its absence from an institution that increasingly exercised powers of life and death over the least privileged members of the international sociely clearly created a dissonance between asserted norms and the actual functioning of power and politics. This was the milieu in which the High-Level Panel was created, and within which its report was formulated.

The High-level Panel Report is in many ways an attempt at balancing the preferences of the dominant post-Cold War intelligentsia for individualized and universalist claims with the realities of practical politics in which the focal points of international order continue to revolve around state power and domestic politics. To appease the desires of the former group, the Report proposed a wide-ranging laundry list of claimed challenges to collective security that, if taken seriously, would convert the vast majority of socio-economic and political problems into issues of international concern, and thereby extinguish virtually any line of demarcation between the functions of the state and those of international society. Of course, given the constellations of hard power and the composition of the panel, the Report did not and could not seriously intend such an outcome. In such an environment, the Report opted for the means that appeared the least threatening to the role of the state within the international system. The result is a lack of fit between the broad sweep of claimed threats to collective security, and the very modest means chosen to realize those objectives. The one significant reform that might have made a difference, the radical reconstitution of the Security Council, was underplayed by the Panel Report eyen as it invoked the Chapter VII powers of the Council as the corefof the new order that it proposed. The best that the Panel Report could do was to restate two models of Security Council reform that had been under consideration for at least a dozen years, and which, even if adopted, would only minimally improve upon the current unrepresentative character of the Security Council, and would do virtually nothing to address the power (rather than law) orientation of the decisions of the Council. ${ }^{43}$

This disjuncture between asserted threats and recommended means for addressing them, while easy to understand, is nonetheless imprudent for the maintenance of international order - that is, for collective security, properly understood. The inclination of the panel in its analysis of the

${ }^{13}$ For a perceptive analysis of the effect of Security Council composition on membership reform. see Farrall. Linted Nations Sanctions and the Rule of Law. 
sources of threats to collective security is to favor the postmodern preference for inclusiveness. Collective security, the Panel Report tells us, is as much about furthering the welfare of the individual citizen as the object of international law as it is about safeguarding national sovereignty; perhaps more so. Therefore, poverty and disease, like terrorism and warfare, are treated in an undifferentiated manner as posing threats to collective security.

Yet, in prescribing responses to these threats, there is a marked difference in the nature of the-legal obligations that the Report imposes on the international system. Socio-economic threats to collective security (such as those involving poverty, the spread of infectious diseases and environmental despoliation), however widespread and lethal, are to be addressed through discretionary collective action, in which traditional norms of state consent and voluntary cooperation predominate. Institutional mechanisms within this framework are at best ad hoc, and depend as much on charity and a sense of moral or ethical obligation as on any conception of binding legal undertakings. On the other hand, threats that emanate from the political sphere - notably those flowing from interstate and internal armed conflicts, terrorism, and the proliferation of weapons of mass destruction - are addressed in a bifurcated manner. In some instances, such threats are to be resolved by employing essentially the same mechanisms as those that dominate in the socioeconomic sphere. In other instances, however, they are to be dealt with through the Security Coungil's Chapter VII powers; which impose mandatory compliance on all thember states of the United Nations.

The question still remains, whatdetermines whether a plitical threat

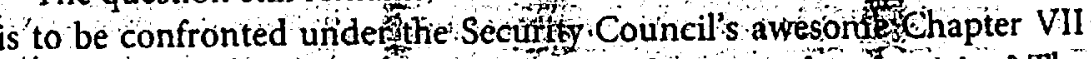
powers, or weakly through the lens of conciliation and coof peration? The answer appears to be practical geo politics. One could hardly be upset with the High-Level Panel for treating this issue solely as a matter of politics, rather than one of law, for in that sense the Panel has merely acknowledged reality as it is practiced. Infused with the post-Cold War neoliberal sensibility in which politics is seen simply as a branch of law (rather than the other way around), it posits an unprincipled legal regime in which big power choices are framed as legal rules. The assumption appears to be that by pretending equality exists, we thereby create it. To be sure, this façade is effective from time to time. There are indeed many good reasons why the international system not only accommodates, but in fact accepts policies that are based on hypocrisy and double standards. The chances that such acceptance can become the norm, rather than the 
exceptional case, is much less likely. A regime of collective security that is grounded on the creed that "the strong do what they can, the weak suffer what they must" can be at best unstable and therefore prone to reverting to a balance of power arrangement.

W'hat then should a stable collective security arrangement entail? In the first place, there is need for a definition of collective security that hews more to implementable policies than to providing the intelligentsia with a virtuous sense of self-righteousness. That contemporary international society, taken as a whole, is immeasurably materially better off than it was even a generation ago is indisputable. That it is morally superior, or even intellectually more sophisticated is, I think, much more debatable. But even if it were, a sense of humility about our individual abilities, or of the human capacity to comprehend and deal with the complexities of the emotions of others, should make the international intelligentsia think twice about the efficacy of policies that are drawn up in post-industrial settings but which are intended to regulate the behavior of operatives well outside that milieu.

The idea of collective security both assumes the existence of inextricably intertwined interests, and that those interests can be selflessly protected by a cabal of international diplomats, civil servants, lawyers, and politicians. Stated in sufficiently abstract terms, there are indeed interests shared by all of humanity. All of humanity would benefit from cleaner rather than dirtier air. It might even be the case that less rather than more poyerty fewer rather than more cases of infectious disease, and certainly alor less violence would be to the good of humanity. But achieving these goals would impose costs, and the distribution of those kinds of costs is often at the heart of disputes within and across societies. It may feel virtuous to overlook those costs in the name of some abstract concept of collective security, but that bliss is purchased at a real cost to many that are not involved in the decision-making process.

Among other considerations, these insights imply a definition of collective security that is less all-encompassing and that is restricted to those areas of interactions whose costs and benefits and, more importantly their distribution, are immediate and transparent. This, in essence, was the seminal insight of the definition of collective security that focused on addressing wars of aggression. It may also be applicable in other areas of human interactions such as dealing with or avoiding imminent transnational financial failures, or the control of pandemic sicknesses. What it does mean is that in elevating concerns over poverty, ordinary infectious diseases, or the transnational trade in narcotics into 
matters of "collective security," this brand name may well be cheapened. This is not because concerns over poverty or the narcotics trade are not well founded, or that such concerns do not deserve international attention, but that in equating issues of international concern with the need for collective security, the international system would be ignoring an essential fact of any successful management scheme: the need to prioritize, and to assign to organs of administration those functions that they are best equipped and competent to resolve. If collective security beemes-no-mere-than-a-synonym for-international cooperation, then we need not assign to the Security Council the special functions and powers that it now enjoys under Chapter VII.

These observations lead to a second crucial point. In the interest of a genuinely practicable collective security regime, the international system needs less, not more centralization. The idea of an all-embracing order, however intuitively appealing it may be to those bred in an ethos of cosmopolitanism, and no matter how technologically feasible, is ultimately debilitating as a legal norm. The point and effect of providing for collective security under Chapter VII is to indicate those instances in which the bulwark of state sovereignty involuntarily must yield to assertions of international power. In these situations, state consent, which is the fuel on which international law ultimately runs, is deemed irrelevant in the face of concerted Security Council action. For reasons provided in the previous paragraph, an overly broad definition of collective security, far from enhancing the legitimacy of the exercose of power under Chapter VII, yndercuts it. Employing such a broäd definition would create a lacuna in international law: the allocation of funithons o the Secirity Council that it is incapable of discharging while simultanteouls y delegitimizing indiydualstates and other traditional internationaldofors be preventing them from providing order within a legal framework

The portended gap mayyâppear theoretical and of minimum consequence for those living in the secure states of Western Europe and North America, but it is real for many whose societies fall into the category of so-called "failing" or "failed" states. International law tends to treat states as static and finished products. That, of course, is far from being an accurate representation. As events in the post-Cold War era have reminded us, states, no less than individuals, are organic living entities that metamorphose from within and respond to external stimuli. Much as one might want them to avoid making mistakes, it is essential that they do in fact make mistakes. There is simply no substitute for learning from the experience of having made errors. 
There is today a tendency to imbue contemporary international paternalism with the sort of altruism that was not uncommon in the decolonization process. It is doubtful that the members of today's international intelligentsia are any more capable of "fixing" the world than the decolonizers were of correcting the mistakes made by their predecessors who were responsible for colonization. What is more, a centralized collective security regime has the potential of denying to the assumed beneficiaries of intervention the experience of shaping their own destiny. In the short run, that may appear fulfilling to those who want to see immediate and tangible results to Security Council actions, but in the longer run, the result, as cases like Somalia amply demonstrate, is likely to be a prolonged arch of insecurity. How long the Security Council, in the name of collective security, would be willing to have the peoples of these societies as its wards is highly dubious. Experiences in the Balkans and Africa raise genuine doubts of the longevity of benign Security Council interest in the affairs of these societies.

A related third reason for a less ambitious and more concrete definition of the concept of collective security is to be found in one of the values of decentralization. In much the same way that biological diversity is more likely to assure ecological survival, it can be said that diversity among political processes is more likely to promote the collective survival of the whole than a standardized uniform political structure. The reasons are several. Human institutions do not arrive fully formed. They are hardly immutable In fact, much of their value derive from the fact that in being tinkored with and constantly reordered they prowide often unwittingly, responses that are imaginatiye and unanticipated Thus unless one wholeheartedly subscribes to the view that human cjuilization has indeed arrived int its zenith (a position that appears sometimes to ingderpin the sanctimonious reverence with which the democratic creed is often professed), the international system would be better off if it were to encourage experimentation among its component parts. To do so, it will have to learn not only to tolerate divergent approaches to problem solving, but to affirmatively support if not empower the independent capacities of members to make correct judgments. A top-down regime of collective security in which purported answers have little more to commend them than that they are backed by the superior material wealth and power of some players within the system is highly unlikely to pernit such experimentation. The more broad sweeping the areas of international relations that are deemed to fall within the province of regulation under the concept of collective security, the less room there will be for experimentation. 
The view that the trade in narcotics, for example, poses a threat to collective security nicely illustrates the point. There is no question that the criminalization of the use of certain narcotics renders illicit the trade in such narcotics, and that the illicitness of the trade breeds violence. There is also evidence that acts of terrorism may be financed by the high profit margins that are derived from the illicit trade. But there is nothing that is implacably intrinsic in the relationship of the trade in narcotics and collective security within the international system. Change an clement-within-the-equation,-and-a very different structure emerges. Suppose that instead of criminalizing the use of narcotics, a society determines to treat such use as a "disease"; that instead of punishing users, they are provided with medical care. We may well find that the incidents of illicit trafficking are reduced, and with it the high profit margins with which the trade is cursently associated. In such an environment, it may well be that the transnational trade in narcotics would amount to little more than hiccoughs in international trade such as those that are now associated with the smuggling of contraband such as cigarettes. The scenario just described can be projected to other areas that the Panel's Report asserts are sources of threats to collective security. Taking a decentralized approach to policy analysis when grappling with statelevel poverty or internal strife, for example, may bear more fruit than treating such issues as threats to the collective security of all within the international system.

Though it may seen queer perhaps more emphasis should be placed on what distinguishes two events than on what they havotomponmon.: For instance, the differea between civil wars waged in thespemoctatic Republic of the Congo and those waged in Colombia and $\mathrm{Per}$ ra are so much more profound than their similarities that anyeffortfo treat then equally as threats to collective security seems misguided Conflicts of ideology over the distribution of national wealth among afi entrenched: elite do not pose the saine threats to international collective security that conflicts between the elite and those struggling for subsistence do, any more than civil wars of secession, fights over who should control the central government, and proxy wars of regional domination do.

Internal wars, especially, cannot be categorically lumped into a collective security threat as are transnational wars. The reason is not that they necessarily entail less human suffering. The quantity of suffering has never been and cannot be the yardstick for gauging the propriety of classifying a situation as constituting a threat to collective security. The measure must be qualitative. The question to be answered must be 
qualitatively framed: Is the situation capable of being resolved effectively by those closest to it; that is, those who are bearing the burden and who will receive the benefit of a resolution? Only if one can confidently state that the affected parties are incapable of independently resolving the conflict, and that there exists a substantial likelihood of the spread of the conflict, should the situation be viewed as one that does in fact involve issues of collective security. Civil wars are notorious for the bitterness, ferocity and lawlessness with which they are waged, but their internationalization does more to prolong their durations than to resolve them. In any event, each case demands particularized assessments of the situation, not a blunt waving of the cudgel by those who at best have an incomplete and sentimental attachment to human suffering. In short, what is needed often is imagination and accommodation, not the superior compassion of those who now view themselves as beyond all of that.

These definitional difficulties are symptomatic of a much more profound source of concern. What makes contemporary debate over the concept of collective security more than an academic one is the reality and pervasiveness of the enforcement role that the Security Council has taken on in the post-Cold War period. That role may have been envisaged by the framers of the United Nations Charter, but it remained for the most part dormant until 1990. The assertiveness of Security Council authority under Chapter VIl since 1990 has rendered significant the use of the Security Council in its resolutions of such verbs as "decides," "deternines" etc. These verbs invariably call into being a series of

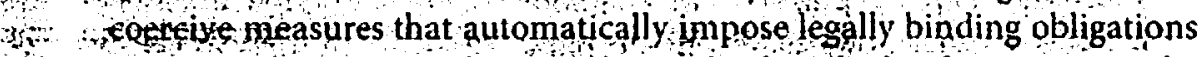
ongancone to whom they are directed Though the decisions may be acriogized pn political grounds and their moratand philosophical legitimagy impugued on representativeness grounds, ultimately they are neittier legally reviewable nor appealable.

Tho willingness of the Council to employ coercive measures has.been cited with much approval as indicative of the international system's ability and willingness to live up to its post-Second World War animating visions. The twin debacles of defining the situations in which the Council may exercise its powers too broadly, and deploying those powers excessively in situations where Council action is appropriate, can be obviated by a much more judicious determination of the choice of the means employed under Chapter VII. It is certainly the case that the Charter provides for at least two distinct approaches by the Security Council with regard to issues of international security. In the one situation, the Council's role is essentially advisory. Under Chapter VI, it may 
cajole, recommend, and implore parties to resolve their disputes amicably. By contrast, under Chapter VII, the Council is a decision maker. It can command and enforce its decisions through coercive measures.

It is the latter role that has become highly controversial, in part because decisions under Chapter VII have become analogous to criminal law enforcement. The Council sets itself up as a prosecutor, purports to render definitive judgments of culpability, and then seeks to punish the miscreant. This approach has been defended on grounds not unlike those typically invoked-by-penologists. The allegedly_culpable state (or, increasingly, individual person) having been convicted must be suffciently punished to deter others from engaging in similar conduct; or else, the international order would be infected by the virus of "impunity." Furthermore, the punishment must be such that the international community obtains retribution from the miscreant. This typically means that the violator must be shamed and ostracized, and be made to give back whatever benefit it may seem to have gained from the violation. To achieve these objectives, the "international community" should be willing to employ coercive measures such as economic sanctions and, if necessary, military force. ${ }^{44}$ The Charter clearly contemplates and authorizes these measures; however, the singular focus on coercion is not compelled by Chapter VII. Indeed, it may undermine the efficacy of Chapter VII.

One source of concern about the system's reliance on pinitive measures is that, as dèmonstrated above, decision making within the Council. G can be extremely biased Q Qverly politicized decisions arejess likely to generate revolt if theyco not notail punishnent: Beyond dis there is a further reason why the Security Council ought to reconsidedts apparent. view that actions under Chapter VII mustilways be backedup by threats of punishment. Were it to free itself of this mindset, it might discover the rich array of administrative incentives that if properly deployed may encourage cooperative behavior-among states, and therby enhance collective security. The absence of coercion in these instances need not mean that Security Council decisions under Chapter VIl would be any less binding. Rather, implementation of decisions under Chapter VII can

${ }^{44}$ Sec, e.g., Gerry Simpson, Great Powers and Outlaw States: Unequal Sovereigns in the International Legal Order (Cambridge: Cambridge University Press, 2004) (noting how the Security Council has adopted increasingly intrusive mechanisms of enforcement against "rogue" or "outlaw" states which it has judged to have defied the basic principles of the international community). 
be hased on the same sort of compliance regimes that regulate behavior elsewhere in international law. For example, there is no philosoptical or legal reason why the Security Council could not make a determination under Chapter VII, and then require that the parties enter into a binding negotiated or even adjudicated resolution of the dispute. Indeed, this was the method used in resolving the Kuwait-Iraq boundary dispute, and that resolution has commanded more acceptance than virtually any of the other Chapter VII decisions taken in regard to the Iraqi conflicts. ${ }^{\text {t5 }}$ Similarly, the provision in the Charter of the International Criminal Court (ICC) which permits the Security Council to make referrals that are then adjudicated by the ICC can be emulated in the Council's practice with regard to issues of collective security. It is true that these approaches facially appear to lack the commanding supremacy of Security Council authoritativeness that has been hailed by post-Cold War neoliberal internationalists, but this disadvantage (if that is what it is) would be amply mitigated by the reconfiguration of ideas of power and legitimacy that would follow.

A division of labor within the international system between the determination of the existence of a threat to collective security, and the adoption of binding means to address that threat, will likely have the salutary effect of depoliticizing the initial determination. Just as prosecutorial decisions are often insulated from political interference by the reality that the ultimate finding of guilt or innocence is entrusted to a thitd party, it may be that many genuine threats to collective security, that

atoday go unaddressed will find a hearing in a world in which Chapter VII -5 determinations are not bound up as a single package of 3 such a disaggregation would also be in keeping with a reality that is too xarely acknowledged: that every body or institution, however constituted, in time develops (or at least prefers) a mode of shaping its competence in a.jinner that may not have been anticipated let alone blessed by its 3

15 This is not to suggest that the role of the Security Council in mandating the demarcation of the boundary between lraq and kuwait was uncontroversial. To the contrary, there were disagreements anong diplomats and academics as to the competence of the Security Council to decide the issue. But the tenor of the disagreements has been along the lines that "reasonable persons" reasonably can disagree on the issue. See, e.g." Frederick L. Kirgis, Ir. "The Security Council's First Fifty Years." 89 A/IL 506 (1995). p. 532; Sean D. Murphy. "Assessing the Legality of Invading Irac." Geo. $L / 1 / 33$ (2004), pp. 187-188. In any event, the Security Council's role in forcing Iraq 10 atcept the boundary lines between her and Kuwait have generated nowhere the level of disenchant. ment in Iray nor among legal scholars as other actions taken purportedly pursuant to Resolution 687 . 
creators. Today's Security Council sees every issue in terms of the exercise of coercive power. In many situations, coercion may be inapt. In such situations, the Security Council either ignores the problem or it resorts to a means that is ill suited to address the problem. Sure, there are sometimes clumsy efforts to transcend the roadblocks of limited competence (such as attempting to create investigative panels over the murder of politicians in polarized societies ${ }^{46}$ ), but the disaggregation of functions would make such efforts less clumsy than they are.

Anether-positive-result-(and one of the often unsung advantages of negotiation as a problem-solving tool) is that it leaves finding an answer in the hands of those who are most competent to do so. Unhappily, in the name of collective security, the myopic tendency increasingly is to assume that the answer lies in the hands of those who can exercise military power. Moreover, criticism of the representativeness (and by extension legitimacy) of the composition of the Security Council, more particularly that of its veto-wielding membership, is likely to diminish in an environment in which the path to "justice" does not automatically and obligatorily lead down the same road. Likewise, parties may be more willing to accept findings of wrongdoing if they are confident that the pronouncement of punishment will not invariably be made by the same biased institution acting as both prosecutor and judge.

Much more can be said about the need to decentralize decision making about collective security. Some have focused on regionalization as the answer, others on the increased use of specialists-Tinall of these cases, however, the Security $C$ ouncil retains ultimate and oqrewieg able author-: ity. The efficacy of som of these proposals is duthang but they do highlight the need for and value of disaggregating pounts of ompetence, even in the sphere of political decision making My oun suggestions would go beyond simply having the Security Council teontract out" some of its Chapter VII functions. It would demand aretfinking of the division of ultimate power in addressing issues of collective security. Nonetheless, the existence of even these other more modest proposals points to the possibilities of dramatically different approaches to the concept of collective security.

The High-Level Panel Report tries to be creative in its articulation of what constitutes collective security. It dares to imagine expanding the

46 See Panel Report paras. 251-253 (proposing two models for the enlargement and reconstitution of the makeup of the Security Council, but explicitly declining to recommend the model that should be adopted). 
scope of the concept. "It is far less imaginative in offering means for addressing the expanded threats. Its answers default to the existing creaky institutions of the system, with a face-lift here and there. There is clearly an unacknowledged tension in these divergent approaches. A narrower definition of collective security would not necessarily result in human needs going unaddressed. It might result simply in empowering other mechanisms and institutions within the system to recognize and address those needs. Similarly, it may be that better results can be achieved from devolving the power and competence of the Security Council; at least the benefit of committing intellectual resources in this direction may be much greater than the perennial head butting that gocs into trying to restructure the Council.

\section{Conclusion}

As the last lines of this chapter are being written, the news media are replete with tragic stories of deaths, suffering, and widespread property destructions that have been caused by two natural disasters in Asia. In the one case, a massive earthquake has destroyed huge swaths of population centers in the Sichuan Province of China. Deaths are being measured in the tens of thousands. Nonetheless, the work of the Chinese government has received quite sympathetic coverage, with the openness of the current government's measures being favorably contrasted with that of a previous Chinese government in an earthquake that occurred in mon 197.6. The second disaster in Myanar a devastating cyclone, has killed Font on to thousands of people and left an even larger number homeless. 0 opinion shapers in the West havebeen anything but sympatheticto this 3 wow tragedy (or more accurately to the response of the government of myanmar to the tragedy). The French government, spearheaded by its $-F$ Foreign Minister, Bernard Kouchner, relying on the concept of collective security" and the asserted "responsibility to protect," has called for Security Council action that would displace and override the policies of the Myanmar government to decide, manage, control, or otherwise regulate the distribution of assistance to sufferers within Myanmar.

Mr. Kouchner, who served, under the auspices of the European Union, as the supreme overlord of Bosnia-Herzegovina, poignantly cuts to the heart of the matter. Nobody, not even the High-Level Panel, had

4- See especially Chapter 5 in this volume on the expanded notion of "responsibility to protect." 
previously argued that natural catastrophes, however extensive, should be deemed threats to collective security. ${ }^{48}$ But given the propensity of natural forces such as earthquakes, hurricanes, and tsunamis to cause massive death and destruction of property, why shouldn't they be viewed as threats to collective security? Mr. Kouchner's comments bring to mind the writings of another well-known Frenchman, Dominique Moisi, who, when addressing differential treatment by continental Europeans and Anglo-Americans over the collective security implications of the invasion and occupation of Iraq-on the one hand, and NATO's intervention in the Balkans on the other, opined, in language remarkably reminiscent of "balance of power" politics:

The result might amount to something like the acceptance of two Monroe Doctrines, with the transatlantic partners each holding sway in certain areas, and on certain issues, that reflect their de facto spheres of interest. Europeans would concentrate on Europe, with a special emphasis on the Balkans and the Mediterranean, and the United States would have priority in the Americas and in Asia. Both Wests would support moderate leaders and promote the rule of law in their respective spheres of influence. They would collaborate in the Middle East, attempting to close the emotional gap between them over the Israeli-Palestinian dispute. And the two sides would also come together over a new doctrine of enlightened interventionism in Africa. ${ }^{49}$

Collective security, it thus might be said, ultimately is about keeping restive societies in check while the rest of us get.on with the business of increasing our wealth and welfare One might be forgiven for asking if this goal is any different from that which undergirded the quest for a balance of power among the Europen states of the nineteenth century The extent of the security that we achieye is not tunrelated to the means we choose. The real difficulty in assuring collective secuitity is that in having excess military power, the cost of employing it may appear small, with the temptation to resort to it before exhaugting other means of control, correspondingly greater. A policy that is based on forcefully keeping the deviant in check renders unnecessary the need to incur the often substantial costs of seeking to understand the sources of the deviancy.

48 On the issue of "nonmilitary" threats, see Chapter 6.

49 See Dominique Moisi, "Reinventing the West," Foreign Affairs 67 (November-December 2003). 